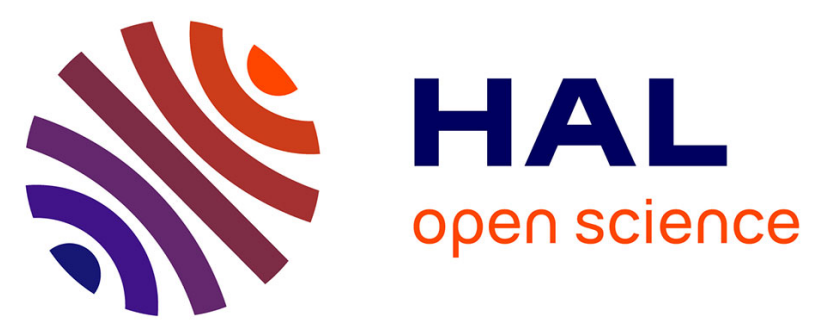

\title{
Meta-Analysis Reveals the Association Between Male Occupational Exposure to Solvents and Impairment of Semen Parameters
}

\author{
Oana Ianos, Irène Sari-Minodier, Virginie Villes, Marie-Pascale \\ Lehucher-Michel, Anderson Loundou, Jeanne Perrin
}

\section{To cite this version:}

Oana Ianos, Irène Sari-Minodier, Virginie Villes, Marie-Pascale Lehucher-Michel, Anderson Loundou, et al.. Meta-Analysis Reveals the Association Between Male Occupational Exposure to Solvents and Impairment of Semen Parameters. Journal of Occupational and Environmental Medicine, 2018, 60 (10), pp.e533-e542. 10.1097/JOM.0000000000001422 . hal-02044732

\section{HAL Id: hal-02044732 \\ https://hal-amu.archives-ouvertes.fr/hal-02044732}

Submitted on 21 Feb 2019

HAL is a multi-disciplinary open access archive for the deposit and dissemination of scientific research documents, whether they are published or not. The documents may come from teaching and research institutions in France or abroad, or from public or private research centers.
L'archive ouverte pluridisciplinaire HAL, est destinée au dépôt et à la diffusion de documents scientifiques de niveau recherche, publiés ou non, émanant des établissements d'enseignement et de recherche français ou étrangers, des laboratoires publics ou privés. 


\title{
Meta-Analysis Reveals the Association Between Male Occupational Exposure to Solvents and Impairment of Semen Parameters
}

\author{
Oana Ianos, MD, Irène Sari-Minodier, MD, PhD, Virginie Villes, MD, \\ Marie-Pascale Lehucher-Michel, MD, PhD, Anderson Loundou, PhD, and Jeanne Perrin, MD, PhD
}

\begin{abstract}
Objectives: Solvent exposure is among the most common occupational exposures to chemical toxicants; data about the impact of such exposure on semen parameters are contradictory. We conducted the first meta-analysis to evaluate the risk of alteration in semen parameters related to occupational exposure to solvents. Methods: From the PubMed database, we selected studies analyzing the semen of subjects occupationally exposed to solvents, compared with unexposed controls. The meta-analysis was performed on the various semen parameters analyzed in both populations. Results: Seven studies were included in the study. The meta-analysis revealed a significant decrease in ejaculate volume [standardized mean difference (SMD) $=-0.35$ $(-0.63$ to -0.07$)]$ and sperm concentration $[\mathrm{SMD}=-0.36(-0.64$ to $-0.08)]$ in workers exposed to solvents compared with unexposed controls. Conclusion: Our results highlight the importance of preventing reprotoxic risks to male fertility in the workplace.
\end{abstract}

Keywords: aromatic hydrocarbons, carbon disulfide, glycol ethers, male fertility., $N$, N-dimethylformamide, perchlorethylene

A mong the risk factors believed to affect male reproductive function are occupational hazards, including various chemical exposures. ${ }^{1}$

Solvent exposures are among the most frequent occupational exposures; these substances, especially organic solvents, are used in a wide variety of activities, including industries (painting, reinforced plastics, electronics, semiconductors, dry cleaning, and textile and leather), in laboratories (pharmaceutical, chemical, biological, or medical testing), and in the services sector (care, cleaning, and cosmetology). ${ }^{2}$

In the plastics industry, the most frequently used solvents are styrene and methylene chloride. ${ }^{3}$ In the painting and printing sectors, paints contain various solvents, including toluene, xylene, ethylbenzene, n-decane, hexane, and glycol ethers (GEs). ${ }^{3,4}$ The main solvents present in the electronics sector and semiconductor industry are GEs.

From the Laboratoire de Biologie de la Reproduction-CECOS, AP-HM La Conception, Pole Parents Enfants, Marseille, France (Drs Ianos, Perrin); AP-HM, La Timone, Service de Médecine et Santé au Travail, Marseille, France (Drs Ianos, Sari-Minodier, Lehucher-Michel); Aix Marseille Univ, Univ Avignon, CNRS, IRD, IMBE, Marseille, France (Drs Sari-Minodier, Perrin); Santé Publique et Maladies Chroniques (SPMC EA 3279), Faculté de Médecine, Aix Marseille Université, Marseille, France (Drs Villes, LehucherMichel, Loundou).

This work was supported by the "CREER" (Couple Reproduction Enfants: Environnement et Risques) project, funded by the "Investissements d'Avenir," French Government Program of the French National Research Agency (ANR) through the A*MIDEX project (No. ANR-11-IDEX-0001-02).

Clinical Significance: The meta-analysis revealed a significant decrease in ejaculate volume and sperm concentration in workers exposed to solvents compared to in unexposed controls. The sperm morphology, viability and motility appeared not significantly decreased in exposed workers. Occupational exposure to solvents should be prevented in male workers of reproductive age.

The authors have no conflicts of interest.

Address correspondence to: Jeanne Perrin, MD, PhD, IMBE Faculté de Médecine sous-sol aile rouge, 27, bd Jean Moulin, 13005 Marseille, France (jeanne.perrin@univ-amu.fr).
However, other solvents, including xylene, n-butyl acetate, acetone, iso-propyl alcohol, and methanol, are also present. ${ }^{3,5}$ In dry cleaning, the main solvent used is perchloroethylene $(\mathrm{PCE})^{3}$; the textile and leather industry involves aliphatic and aromatic petroleum solvents other than benzene and chlorinated solvents. Laboratory activities can expose a worker to benzene, toluene, xylene, chloroform, methylene chloride, formaldehyde, isopropanol, or chloroform. The health care sector involves the use of sterilization products, some of which contain toluene or xylene. ${ }^{6}$

Although some cross-sectional studies of the exposed/unexposed type $\mathrm{e}^{7-10}$ or case-control ${ }^{11,12}$ have described various kinds of solvents affecting semen parameters, other exposed/unexposed studies did not find any significant association between the alteration of semen parameters and occupational exposure to these agents, although other effects were noticed (genotoxicity and decreased libido). ${ }^{13-15}$ Given the contradictory data on this issue, the objective of our work was to conduct a meta-analysis to assess the risk of semen parameter impairment in relation to occupational exposure to solvents.

\section{METHODS}

\section{Research Strategy}

We carried out a literature search of articles studying semen parameters in solvent-exposed workers; for the meta-analysis, we followed the recommendations of the Preferred Reporting Items for Systematic Review and Meta-analyses (PRISMA) (http:// www.prisma-statement.org).

Eligible publications were identified by a specific search from the PubMed database using the following Medical Subject Headings (MESH) terms: "solvents," "occupational exposure," "semen analysis," "infertility, male," and "hydrocarbons" with the filter "human." We reviewed lists of bibliographic references of relevant articles to identify additional references. We did not have any publication date limit, and the search was carried out until June 30, 2017.

\section{Inclusion and Exclusion Criteria}

We retained all articles with abstracts, published in referenced scientific journals in English or in French that analyzed the relationship between occupational exposure to solvents and semen parameters.

Among these, we included studies analyzing semen parameters in men classified as occupationally exposed compared with those not exposed (controls) in the meta-analysis.

We excluded studies that met the following criteria:

(1) Case-control studies that analyzed occupational exposures to solvents in infertile versus fertile patients or that analyzed semen parameters in infertile patients exposed or not exposed to solvents;

(2) Articles that met the inclusion criteria but did not provide the data necessary for the meta-analysis and/or the methodology of semen analysis; and

(3) Studies that were different but were based on the same research and provided the same results. 


\section{Data Extraction}

For each study meeting inclusion criteria, the following data were extracted: first author, country, year of publication, solvent(s) implicated, and population size (number of solvent-exposed workers vs unexposed workers), area of activity, exposure measurement (airborne and/or biomonitoring), and the mean and standard deviation (SD) of semen parameters analyzed in each group. We contacted the authors of articles that did not provide all the semen data in order to try to obtain them.

\section{Semen Parameters Analyzed in the Meta-analysis}

The available studies addressed the issue of semen disorders by analyzing five parameters: ejaculate volume, sperm concentration, morphology, viability, and motility.

Each semen parameter was analyzed separately. As sperm morphology and sperm motility were expressed with various units and classifications, for each parameter, we took into consideration the unit that was used in the majority of studies: for sperm morphology, we considered the percentage of abnormal forms, and for sperm motility, we considered the percentage of progressive sperm.

\section{Statistical Analysis}

The analyses were performed with STATA statistical software package, version 13.1 (Copyright 1985 to 2013; StataCorp LLC, TX) using the command metan.

The results were expressed as a standardized mean difference (SMD) that is interpreted as the difference between the means of the two groups (exposed and unexposed) and divided by the pooled SD of the measurements. The SMD was calculated with $95 \%$ confidence intervals (95\% CIs) for each study. Among the various methods used to combine the results of different studies in a meta-analysis, one of the most used is based on a two-assumption model. One of them is the fixed-effect model that presumes the weight of each study by the inverse of its variance (within-studies). ${ }^{16}$ In the random-effect model, ${ }^{17}$ each study is weighted by the inverse of its variance including the original (within-studies) variance and the betweenstudies variance. Using the $I^{2}$ statistic, we evaluated heterogeneity, as it represents the percentage of variance due to between-study factors rather than sampling error. ${ }^{18}$ We applied a random-effects model, as we considered values of $I^{2}$ more than 50\% to represent large heterogeneity. ${ }^{19}$ The SMD with corresponding CI for each study and the overall random effect pooled estimate were shown in generated forest plots. We used funnel plots to check for the existence of publication bias when appropriate. ${ }^{20}$

\section{RESULTS}

\section{Study Selection}

The bibliographic research retrieved a total of 75 articles. Of

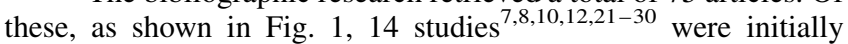
selected, as they fulfilled the inclusion criteria. We included seven more articles ${ }^{13-15,31-34}$ from the references cited in relevant articles obtained by the search strategy. We then excluded 14 articles for the following reasons:

(1) Five case-control studies ${ }^{12,23-26}$;

(2) Eight studies meeting the inclusion criteria but with no data necessary for the meta-analysis available and/or the methodology of semen analysis $7,8,10,13-15,21,22$; and

(3) One duplicate study. ${ }^{28}$

\section{Characteristics of the Studies}

A total of 272 exposed and 247 unexposed control men providing a semen sample were included; the lowest number of men per study was 20, and the highest was 113 . Three studies were
conducted in China/Taiwan, ${ }^{27,33,34}$ three in the USA, ${ }^{30-32}$ and one in Mexico. ${ }^{29}$

For sperm morphology analysis, the percentage of abnormal forms was presented in three studies of the seven selected; we included only two ${ }^{33,34}$ studies in the meta-analysis using World Health Organization (WHO) sperm morphology classification because the third one ${ }^{30}$ used another classification to determine the rate of abnormal forms. ${ }^{35}$ For sperm motility analysis, we included five studies that provided the percentage of progressive motility, ${ }^{29-33}$ and for sperm vitality analysis, the five studies that provided the values ${ }^{27,29,31,32,34}$ (Table 1).

\section{Pooled Analysis of the Effect of Occupational Exposures on Semen Parameters}

Table 1 summarizes the population characteristics, types of implicated solvent, methods for exposure measurement, and semen analysis. Three of seven studies showed a significant impairment of one or several semen parameters in exposed men versus controls: ejaculate volume in workers exposed to carbon disulfide $\left(\mathrm{CS}_{2}\right),{ }^{34}$ sperm concentration and sperm morphology in workers exposed to aromatic solvents and $\mathrm{CS}_{2},{ }^{29,34}$ sperm viability in workers exposed to $\mathrm{CS}_{2},{ }^{34}$ and sperm motility in workers exposed to aromatic solvents and N,N-dimethylformamide (DMF). ${ }^{29,33}$

Only one study ${ }^{29}$ calculated odds ratios (ORs) to quantify the risk of semen parameter alterations in exposed men compared with controls; they showed a statistically increased higher risk for sperm concentration impairment [OR $(95 \% \mathrm{CI})=14.13$ (3.60 to 78.72$)]$, for morphology impairment $[\mathrm{OR}=27.82, P<0.001]$, and for motility $[\mathrm{OR}(95 \% \mathrm{CI})=9.67$ (3.11 to 32.91$)]$. In the other studies, the results showed impairment (statistically significant or not) of at least one semen parameter in exposed men compared with controls. Conversely, some studies revealed sperm parameters that are not altered or even better (but not statistically significantly) in the exposed workers comparing to controls; this is the case for ejaculate volume in one study regarding aromatic solvents, ${ }^{29}$ sperm concentration in one study regarding aromatic solvents, ${ }^{27}$ sperm morphology in one study regarding PCE, ${ }^{30}$ and sperm viability and motility in two studies regarding GE. ${ }^{3}$

Statistical analysis showed heterogeneous results (heterogeneity index $I^{2}>50 \%$ ); consequently, we used a random-effects model rather than a fixed-effects model.

We observed a significant decrease in ejaculate volume $[\mathrm{SMD}(95 \% \mathrm{CI})=-0.35(-0.63$ to -0.07$)]$ and sperm concentration $[\mathrm{SMD}(95 \% \mathrm{CI})=-0.36(-0.64$ to -0.08$)]$ in exposed men versus controls (Fig. 2). The heterogeneity index $I^{2}$ was $57.1 \%$ $(P=0.030)$ for ejaculate volume and $58.6 \%(P=0.024)$ for sperm concentration (Fig. 2).

Sperm morphology, viability, and motility were not significantly reduced: SMD $(95 \% \mathrm{CI})=1.06(-0.15$ to 2.27$)$ for $\%$ abnormal morphology sperm, SMD $(95 \% \mathrm{CI})=-0.67(-1.48$ to $0.13)$ for $\%$ live sperm, and SMD $(95 \% \mathrm{CI})=-0.44(-1.10$ to 0.23$)$ for $\%$ motile sperm (Fig. 3). The heterogeneity index $I^{2}$ was $81.6 \%$ for morphology, $93.3 \%$ for viability, and $89.1 \%$ for motility ( $P=0.02$ for sperm morphology and $P<0.001$ for sperm viability and motility).

\section{DISCUSSION}

To the best of our knowledge, this is the first meta-analysis studying the impact of occupational exposure to solvents on semen parameters. We showed that occupational exposure to solvents was associated with a significant impairment of ejaculate volume and sperm concentration in exposed workers compared with unexposed workers. 


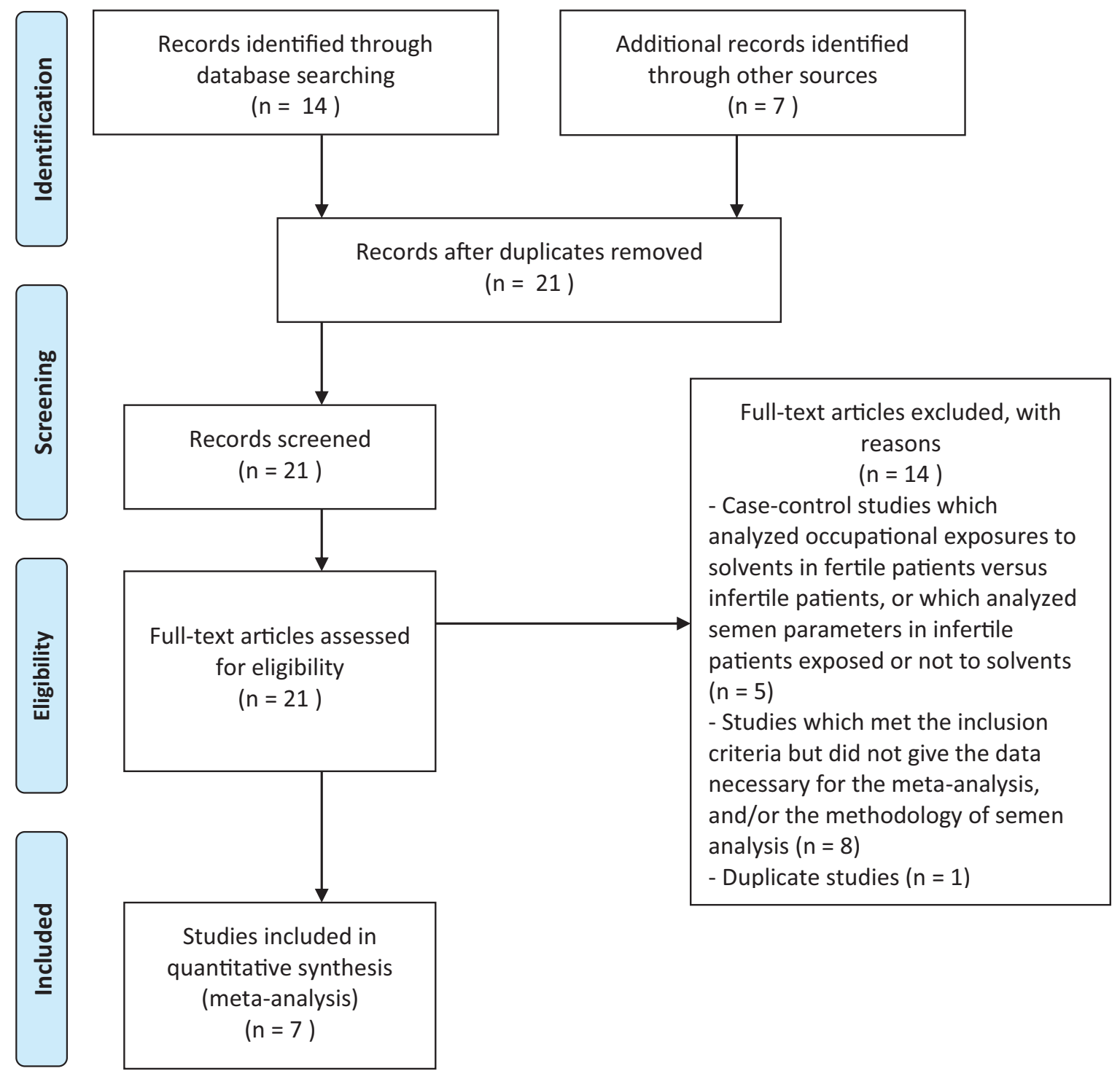

FIGURE 1. PRISMA flow diagram of the identification, screening, and inclusion phases of the study selection.

Sperm concentration and ejaculate volume are related to male fertility. Indeed, Cooper et $\mathrm{al}^{36}$ showed in a large international study that men in the reference most fertile population were characterized by a larger ejaculate volume and a higher sperm concentration than men in general population. Ejaculate volume and sperm concentration influences fertility by impacting the total sperm count in the ejaculate. Ejaculate volume is mainly related to the secretion of seminal vesicles, which are well known to be androgen-dependent glands. ${ }^{37}$

A strong point of the selection process in our meta-analysis is that we included work-based studies comparing semen parameters between exposed and unexposed populations. We eliminated studies comparing semen analysis data in fertile versus infertile men attending fertility clinics, that is, five case-control studies from our bibliographic research. ${ }^{12,23-26}$ In these studies, men were classified as exposed and not exposed based on their job and occupational exposures collected by means of questionnaire; job exposure matrix was also used. ${ }^{12,26}$ Using this design, it is difficult to characterize the various exposures, the types of solvents and to define properly exposed and unexposed subjects, especially for an exposure as broad as solvents. Therefore, we preferred to select only studies conducted in the workplace to ensure that exposed subjects were really occupationally exposed to solvents and that the controls were not. Among the 15 studies meeting these inclusion criteria, only seven studies provided all the data needed to be included in the meta-analysis.

The homogeneous design of the selected studies insured a detailed evaluation of the level of exposure to solvents by airborne concentrations and/or biomonitoring. In the study by Welch et al, ${ }^{31}$ painters in a large shipyard had exposure to 2-methoxyethanol (2$\mathrm{ME})$ and 2-ethoxyethanol (2-EE) through aerosol and skin contact. The industrial hygiene survey assessing the atmospheric concentrations and analysis of urine metabolites [methoxyacetic acid (MAA) for 2-ME and ethoxyacetic acid (EAA) for 2-EE] documented that the painters were exposed to GE, while the controls were not. ${ }^{31}$ Moreover, about half of the participants were considered exposed to lead, a known reproductive toxin. In the study by Ratcliffe et $\mathrm{al}^{32}$ conducted in a metal castings company, full shift breathing zone exposure to 2-EE was measured and was completed by EAA in urine and 2-EE in blood, the latter giving results below 


\begin{tabular}{|c|c|c|c|c|c|c|c|c|c|}
\hline \multirow[b]{2}{*}{ Ref. } & \multirow[b]{2}{*}{ Solvents } & \multirow[b]{2}{*}{$\begin{array}{c}\text { Exposure } \\
\text { Measurement }\end{array}$} & \multirow[b]{2}{*}{$\begin{array}{l}\text { Populations } \\
\quad(n)\end{array}$} & \multirow[b]{2}{*}{$\begin{array}{l}\text { Occupational } \\
\text { Activity }\end{array}$} & \multicolumn{5}{|c|}{$\begin{array}{c}\text { Semen Analysis } \\
\text { Mean } \pm \text { SD, Median [Range] } \\
P \text { (if Significant Difference Between Exposed and Unexposed) }\end{array}$} \\
\hline & & & & & Volume, $\mathrm{mL}$ & $\begin{array}{c}\text { Concentration, } \\
\text { millions } / \mathrm{mL}\end{array}$ & $\begin{array}{l}\text { Abnormal } \\
\text { Forms (\%) }\end{array}$ & $\begin{array}{l}\text { Viability } \\
(\%)\end{array}$ & $\begin{array}{l}\text { Progressive } \\
\text { Motility (\%) }\end{array}$ \\
\hline \multirow[t]{2}{*}{$\begin{array}{l}\text { Welch et } \mathrm{al}^{31} \\
\text { USA }\end{array}$} & $\begin{array}{l}\text { 2-methoxyethanol (2-ME) } \\
\text { 2-ethoxyethanol (2-EE) }\end{array}$ & $\begin{array}{l}\text { 2-ME and 2-EE airborne } \\
\text { concentrations } \\
\text { Urinary metabolite } \\
\text { levels (methoxyacetic } \\
\text { acid for 2-ME and } \\
\text { ethoxyacetic acid for } \\
\text { 2-EE) }\end{array}$ & Exposed (73) & $\begin{array}{l}\text { Painters in a large } \\
\text { shipyard }\end{array}$ & $2.52 \pm 1.2$ & $66.5 \pm 40.3$ & NA & $67.9 \pm 13.6$ & $34.5 \pm 15.2$ \\
\hline & & & $\begin{array}{l}\text { Not exposed } \\
\quad(40)\end{array}$ & $\begin{array}{l}\text { Clerks and marine } \\
\text { draftsmen in the } \\
\text { same shipyard }\end{array}$ & $2.88 \pm 1.3$ & $78.6 \pm 53.9$ & NA & $62.3 \pm 16.3$ & $33.4 \pm 16.1$ \\
\hline \multirow[t]{2}{*}{$\begin{array}{l}\text { Ratcliffe } \\
\text { et al }{ }^{32} \\
\text { USA }\end{array}$} & 2-EE & $\begin{array}{l}\text { 2-EE airborne } \\
\text { concentration } \\
\text { Urinary metabolite } \\
\text { level (ethoxyacetic } \\
\text { acid) } \\
\text { Blood 2-EE level }\end{array}$ & Exposed (37) & $\begin{array}{l}\text { Workers in the } \\
\text { investing } \\
\text { department in a } \\
\text { metal castings plant }\end{array}$ & $2.8 \pm 1.3$ & $48.5 \pm 30.2$ & NA & $71.5 \pm 10.1$ & $43.9 \pm 10.5$ \\
\hline & & & $\begin{array}{l}\text { Not exposed } \\
\quad(38)\end{array}$ & $\begin{array}{l}\text { Workers from } \\
\text { elsewhere in the } \\
\text { plant }\end{array}$ & $3.1 \pm 1.4$ & $60.2 \pm 37.0$ & NA & $71.2 \pm 9.1$ & $40.4 \pm 12.3$ \\
\hline \multirow{2}{*}{$\begin{array}{l}\text { Eskenazi } \\
\text { et al } \\
\text { USA }\end{array}$} & Perchloroethylene (PCE) & $\begin{array}{l}\text { Expired air levels of } \\
\text { PCE }\end{array}$ & Exposed (34) & Dry cleaners & $2.7 \pm 1.3$ & $84.7 \pm 76.1$ & $42.1 \pm 11.9$ & NA & $61.8 \pm 18.5$ \\
\hline & & & $\begin{array}{l}\text { Not exposed } \\
\quad(48)\end{array}$ & $\begin{array}{l}\text { Matched-age laundry } \\
\text { workers }\end{array}$ & $3.0 \pm 1.7$ & $87.0 \pm 87.1$ & $44.4 \pm 11.5$ & NA & $66.0 \pm 17.0$ \\
\hline \multirow[t]{2}{*}{$\begin{array}{l}\text { De Celis } \\
\quad \text { et al }^{29} \\
\text { Mexico }^{2}\end{array}$} & $\begin{array}{l}\text { Ethylbenzene } \\
\text { Benzene } \\
\text { Toluene } \\
\text { Xylene }\end{array}$ & $\begin{array}{l}\text { Solvent airborne } \\
\text { concentrations }\end{array}$ & Exposed (48) & $\begin{array}{l}\text { Workers in production } \\
\text { area of rubber } \\
\text { factory }\end{array}$ & $\begin{array}{c}2.5 \pm .4 \\
2.5[0.7-5.7]\end{array}$ & $\begin{array}{c}13 \pm 38^{\mathrm{c}} \\
12.5[0-155]\end{array}$ & $\begin{array}{l}\text { Normal forms }(\%): \\
\quad 32 \pm 10^{* * *} \\
\quad 30[16-57]\end{array}$ & $\begin{array}{c}85 \pm 9 \\
88[44-98]\end{array}$ & $20 \pm 24^{\mathrm{c}} 37[0-78]$ \\
\hline & & & $\begin{array}{l}\text { Not exposed } \\
\quad(42)\end{array}$ & $\begin{array}{l}\text { Workers in } \\
\text { administrative } \\
\text { offices }\end{array}$ & $\begin{array}{c}2.5 \pm 0.9 \\
2.6[1.0-5.0]\end{array}$ & $\begin{array}{l}60 \pm 57^{\mathrm{c}} \\
66[8-270]\end{array}$ & $\begin{array}{c}\text { Normal forms }(\%): \\
42 \pm 11^{\mathrm{c}} \\
43[28-67]\end{array}$ & $\begin{array}{c}90 \pm 5 \\
90[73-96]\end{array}$ & $52 \pm 19^{\mathrm{c}} 62[10-87]$ \\
\hline \multirow[t]{2}{*}{$\begin{array}{c}\text { Chang et } \mathrm{al}^{33} \\
\text { Taiwan }\end{array}$} & $\begin{array}{l}\mathrm{N}, \mathrm{N}-\text { dimethylformamide } \\
\text { (DMF) }\end{array}$ & $\begin{array}{l}\text { DMF airborne } \\
\text { concentration Urinary } \\
\text { metabolite level } \\
\text { (N-methylformamide) }\end{array}$ & Exposed (12) & $\begin{array}{l}\text { Workers exposed in a } \\
\text { synthetic leather } \\
\text { factory }\end{array}$ & $2.3 \pm 1.0$ & $106.2 \pm 95.0$ & $49.6 \pm 15.2$ & NA & $49.6 \pm 15.1^{\mathrm{a}}$ \\
\hline & & & $\begin{array}{l}\text { Not exposed } \\
\quad(8)\end{array}$ & $\begin{array}{l}\text { Socioeconomically } \\
\text { matched workers } \\
\text { from another non- } \\
\text { DMF exposed } \\
\text { manufacturing plant }\end{array}$ & $2.4 \pm 0.7$ & $120.4 \pm 73.2$ & $45.4 \pm 9.0$ & NA & $64.2 \pm 12.7^{\mathrm{a}}$ \\
\hline
\end{tabular}




\section{TABLE 1. (Continued)}

Semen Analysis

Mean \pm SD, Median [Range]

$P$ (if Significant Difference Between Exposed and Unexposed)

\begin{tabular}{|c|c|c|c|c|c|c|c|c|c|}
\hline Ref. & Solvents & $\begin{array}{c}\text { Exposure } \\
\text { Measurement }\end{array}$ & $\begin{array}{c}\text { Populations } \\
(n)\end{array}$ & $\begin{array}{l}\text { Occupational } \\
\text { Activity }\end{array}$ & Volume, $\mathbf{m L}$ & $\begin{array}{c}\text { Concentration, } \\
\text { millions } / \mathbf{m L}\end{array}$ & $\begin{array}{c}\text { Abnormal } \\
\text { Forms (\%) }\end{array}$ & $\begin{array}{c}\text { Viability } \\
(\%)\end{array}$ & $\begin{array}{c}\text { Progressive } \\
\text { Motility (\%) }\end{array}$ \\
\hline \multirow[t]{2}{*}{$\begin{array}{c}\text { Xiao et } \mathrm{al}^{27} \\
\text { China }\end{array}$} & $\begin{array}{c}\text { Benzene } \\
\text { Toluene } \\
\text { Xylene }\end{array}$ & $\begin{array}{l}\text { Solvent airborne } \\
\text { concentrations } \\
\text { Solvent blood and } \\
\text { semen concentrations }\end{array}$ & Exposed (24) & $\begin{array}{l}\text { Exposed workers } \\
\text { (shoemaking, spray } \\
\text { painting or paint } \\
\text { manufacturing) }\end{array}$ & $2.34 \pm 1.47$ & $85.84 \pm 75.88$ & NA & $58.95 \pm 15.60$ & NA \\
\hline & & & $\begin{array}{l}\text { Not exposed } \\
\quad(37)\end{array}$ & $\begin{array}{l}\text { Age- and occupational- } \\
\text { matched } \\
\text { nonexposed } \\
\text { controls with } \\
\text { similar physical } \\
\text { activity selected } \\
\text { from managers }\end{array}$ & $2.90 \pm 0.95$ & $82.26 \pm 45.58$ & NA & $72.63 \pm 6.98$ & NA \\
\hline \multirow[t]{2}{*}{$\begin{array}{l}\text { Ma et } \mathrm{al}^{34} \\
\text { China }\end{array}$} & Carbon disulfide $\left(\mathrm{CS}_{2}\right)$ & $\begin{array}{l}\mathrm{CS}_{2} \text { airborne } \\
\text { concentrations }\end{array}$ & Exposed (44) & $\begin{array}{l}\text { Exposed workers from } \\
\text { filature and cotton } \\
\text { pulp departments of } \\
\text { a fabric factory }\end{array}$ & $2.9 \pm 1.2^{\mathrm{c}}$ & $68.0 \pm 40.0^{\mathrm{b}}$ & $19.8 \pm 6.1^{\mathrm{c}}$ & $65.6 \pm 11.9^{\mathrm{c}}$ & NA \\
\hline & & & $\begin{array}{l}\text { Not exposed } \\
\quad(34)\end{array}$ & $\begin{array}{l}\text { Unexposed workers } \\
\text { from the same } \\
\text { factory }\end{array}$ & $4.2 \pm 1.1^{\mathrm{c}}$ & $90.8 \pm 26.5^{\mathrm{b}}$ & $12.5 \pm 3.3^{\mathrm{c}}$ & $85.6 \pm 7.6^{\mathrm{c}}$ & NA \\
\hline
\end{tabular}

NA, not available.

${ }^{\mathrm{a}} P<0.05$.

$P<0.001$ (between exposed and not exposed populations). 


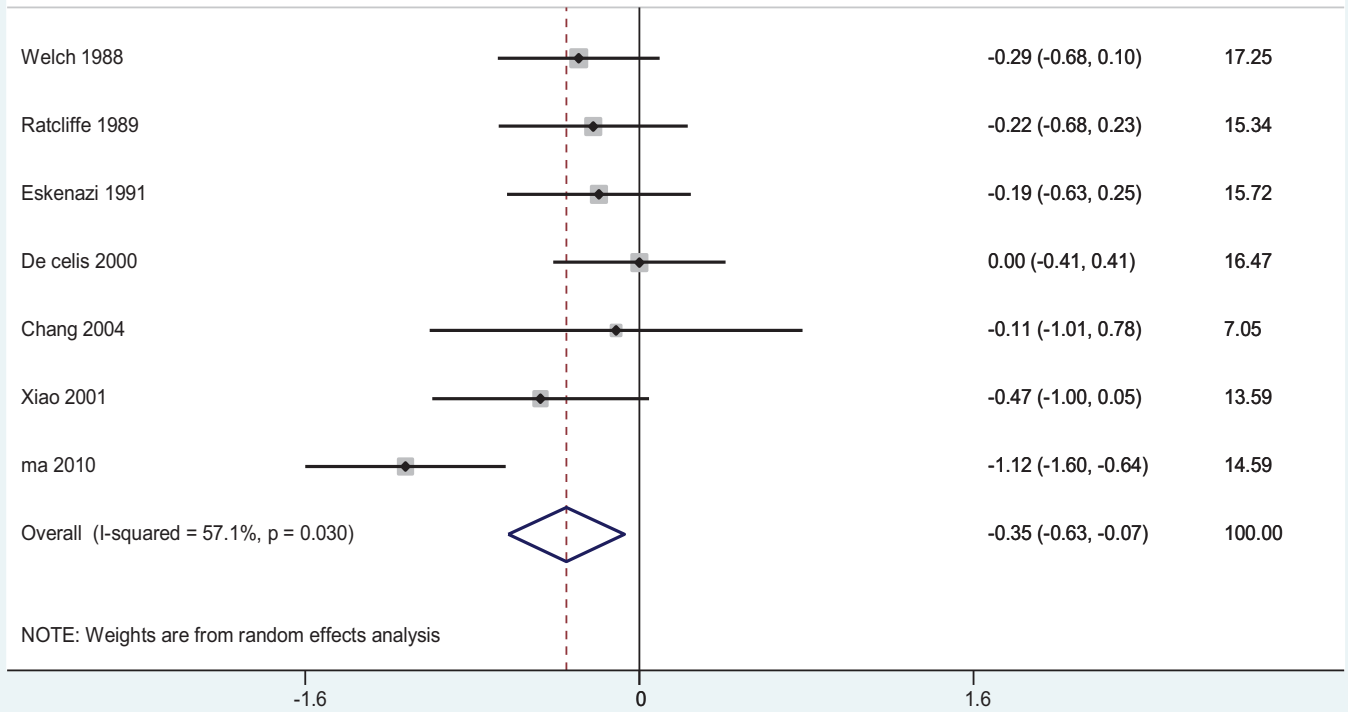

A

Study

ID
$\%$

$\operatorname{SMD}(95 \% \mathrm{Cl})$

Weight

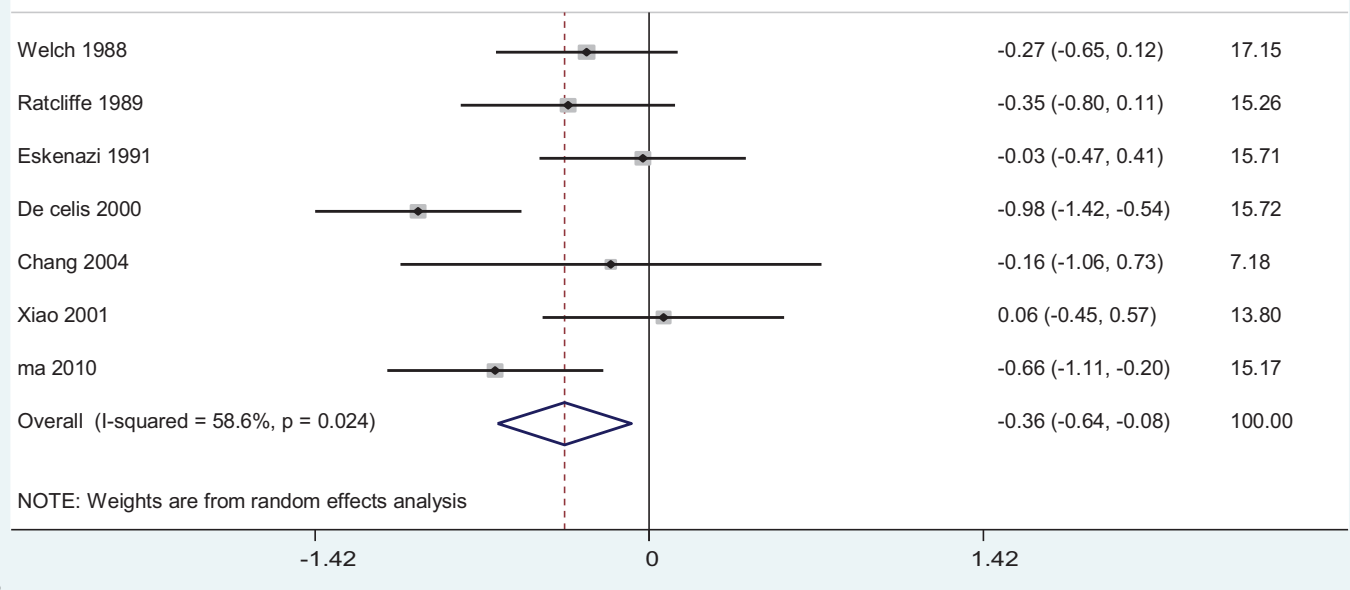

B

FIGURE 2. Forest plots of studies on ejaculate volume (A) and sperm concentration (B) among solvent-exposed male workers.

the detection limit. ${ }^{32}$ Other reprotoxic exposures were reported by workers in the control group and some from the group exposed to 2$\mathrm{EE}$, including metal fumes and dusts, other solvents (eg, PCE), or heat and vibration.

For PCE exposure, Eskenazi et $\mathrm{al}^{30}$ examined the relationships between semen parameters and expired air levels of this solvent using an exposure index based on job tasks in the previous
3 months (period of spermatogenesis) in dry cleaners and laundry workers (controls). ${ }^{30}$ The dry cleaners exhaled higher levels of PCE than did the laundry workers, but the latter reported working under hotter conditions.

For aromatic solvents, De Celis et $\mathrm{al}^{29}$ used continuous monitoring of all rubber factory areas during the workday, revealing significant levels of ethylbenzene, benzene, toluene, 


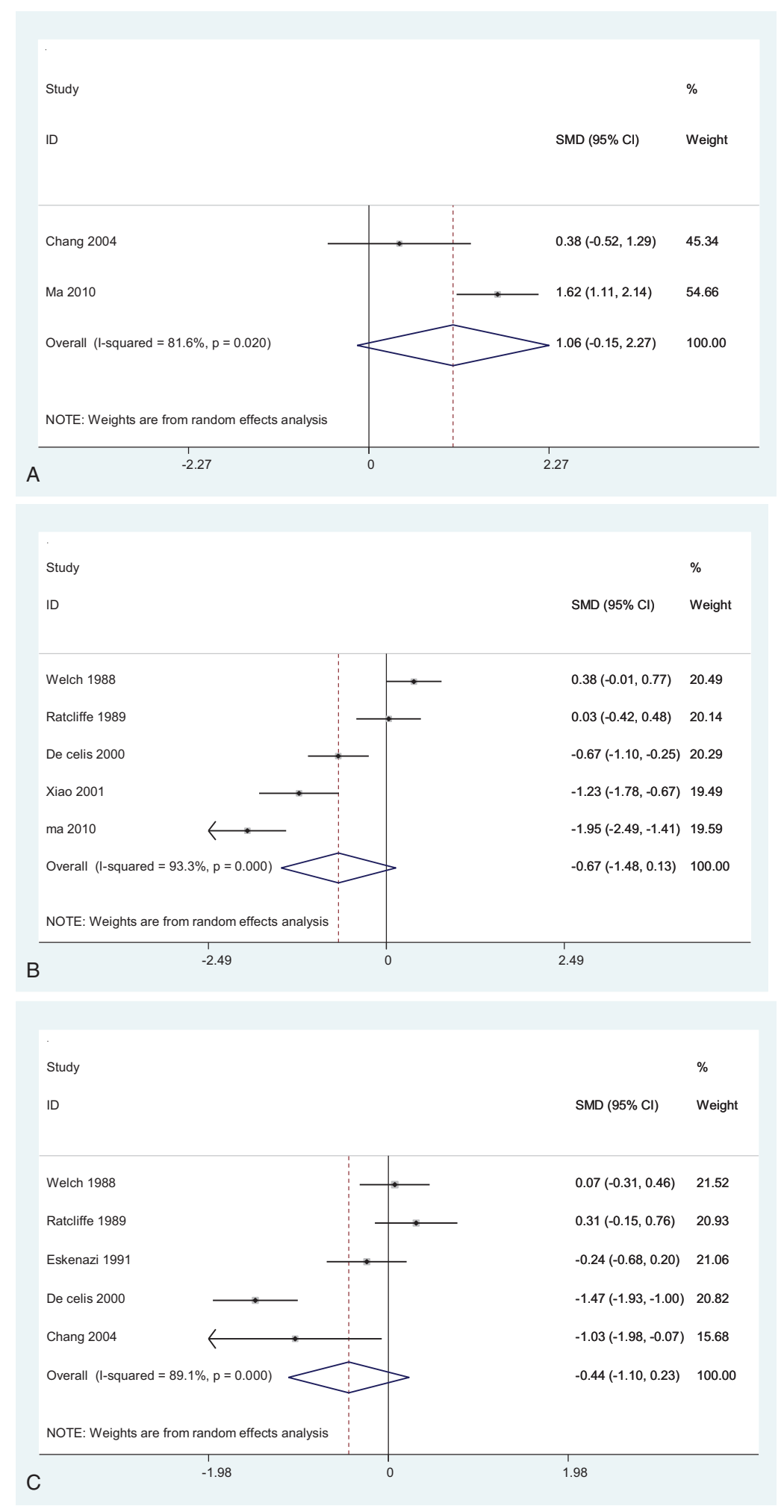

FIGURE 3. Forest plots of studies on $\%$ of sperm with abnormal morphology (A), \% sperm viability (B), and \% sperm motility (C) among solventexposed male workers.

and xylene. In the study by Xiao et al, ${ }^{27}$ the air concentration of benzene, toluene, and xylene in workplaces (shoemaking, spray painting, paint manufacturing) exceeded the maximum allowable concentration (MAC) in China. The authors also measured these three solvents in the subject's blood and semen; they were detected in exposed workers (not all) but were not found in the control group.

In the study by Chang et $\mathrm{al}^{33}$ in a synthetic leather factory in Taiwan, breathing-zone monitoring of DMF exposure covering the full work shift and urinary dosing of N-methylformamide (NMF) (a 
DMF metabolite) were implemented for each participant. None of the controls had detectable airborne DMF nor urinary NMF. In exposed subjects, sperm motility was negatively related to urinary NMF but was not related to airborne DMF.

Ma et $\mathrm{a}^{34}$ recruited workers from the filature and cotton pulp departments of a fabric factory in China and referred to airborne monitoring spots for $\mathrm{CS}_{2}$ over 3 years, levels known to be higher than the MAC in China.

A limit of the selected studies is the participation rate, which is low, as usually observed in studies of semen quality of workers. The authors specified the participation rates for four studies of seven. The participation rates in exposed and control workers were $43 \%$ and $92 \%$ for Xiao et al, ${ }^{27} 38 \%$ and $34 \%$ for Eskenazi et al, ${ }^{30}$ $50 \%$ and $32 \%$ for Welch et $\mathrm{al}^{31}$ and $50 \%$ and $26 \%$ for Ratcliffe et al, respectively. ${ }^{32}$ Low participation rate may result in bias if men with known infertility problems are more likely to participate in exposed group than in the unexposed group or vice versa. Welch et $\mathrm{al}^{31}$ conducted a follow-up survey of a group of exposed and control nonparticipants; they concluded that the man who participated were not more likely to have a fertility problem than those who declined to participate.

Concerning the characteristics of the populations, controls were age matched with exposed workers in some studies $27,30,33$ or showed no statistical difference in age, ${ }^{29}$ tobacco, and alcohol consumption. ${ }^{27,30,32,33}$ The groups did differ in these factors that may affect semen analysis, in the study by Welch et al. ${ }^{31}$ Other differences existed in the level of employment or education or geographical origin. ${ }^{27,30}$

The meta-analysis revealed a significant decrease in ejaculate volume in relation to solvent exposure, while a statistically significant impairment of ejaculate volume was shown in only one study (44 men exposed to $\mathrm{CS}_{2}$ vs 34 controls) of the seven studies included in the meta-analysis. ${ }^{34}$ According to the European harmonized classification, $\mathrm{CS}_{2}$ is suspected of damaging fertility and the unborn child (category 2). ${ }^{38}$

As stated in the literature, the mechanism of action of $\mathrm{CS}_{2}$ on ejaculate volume could be an impairment of libido and sexual functions by hormonal disruption (gonadotropin and testosterone alterations) ${ }^{15,39}$ that could impact ejaculation. In workers exposed to DMF, hormonal disruption could also be involved in the decrease in ejaculate volume. ${ }^{40}$ For the other types of solvents included in the meta-analysis, no known mechanism of action could be associated with a decrease in ejaculate volume.

Similarly, although the meta-analysis showed a significant impairment of sperm concentration, only two studies included in the meta-analysis revealed such a significant result: 44 men exposed to $\mathrm{CS}_{2}$ versus 34 controls $^{34}$ and 48 workers exposed to aromatic solvents versus 42 controls. $^{29}$ According to the literature, the mechanism of action of $\mathrm{CS}_{2}$ on sperm concentration could be hormonal disruption (gonadotropin and testosterone alterations) ${ }^{15,39}$ and the induction of apoptosis in immature germ cells, possibly impacting spermatogenesis. ${ }^{41}$

For aromatic solvents, the potential mechanisms of action on sperm concentration vary depending on the type of solvent. According to the European classification, toluene is suspected of damaging the unborn child but not fertility. ${ }^{38}$ Only one in vivo animal study described spermatogenesis impairment ${ }^{42}$; these findings indicated that toluene did not directly affect spermatogenic cells within the testis but may act on spermatozoa within the epididymis in rats. No data are available for humans regarding toluene's impact on semen parameters. A Swedish occupational study ${ }^{43}$ showed decreasing plasma concentrations of $\mathrm{LH}$ and testosterone associated with increasing exposure concentrations of toluene. Conforming to the European classification, benzene may cause genetic defects (mutagenic on germ cells, category $1 \mathrm{~B}$ ) and cancer (category $1 \mathrm{~A}),{ }^{38}$ but it is not considered toxic for reproduction. Nevertheless, several publications conducted in humans exposed to benzene reported impairment of semen parameters and sperm nuclei. ${ }^{9,10,44,45}$ According to the literature, the mechanism of action could involve DNA damage in immature germ cells $\mathrm{s}^{45,46}$ and cytotoxicity via critically toxic metabolites and free radicals. ${ }^{47}$ Xylene and ethyl benzene are not classified as toxic for reproduction because of a lack of robust data.

In another study, not included in the meta-analysis, Multigner et $\mathrm{al}^{21}$ described a significant decrease in sperm concentration in workers exposed to GE. They suspected that the mechanism of action was related to MAA, the main metabolite of GE, that could be toxic to DNA synthesis and cytochrome $\mathrm{C}$ oxidase.

A statistically significant decline of sperm concentration was also described in workers exposed to styrene in the reinforced plastics industry. ${ }^{8}$ Conversely, no such differences in semen concentration between exposed versus unexposed group were found in other studies. ${ }^{7,14}$

The meta-analysis showed no significant impact of occupational exposure to solvents on morphology, viability, and motility of spermatozoa. For the analysis of sperm morphology, the seven selected studies were very heterogeneous; consequently, we could only include two studies with the same methodology. ${ }^{33,34}$ Indeed, three studies did not analyze sperm morphology, ${ }^{27,31,32}$ one expressed the sperm morphology by $\%$ of normal forms, ${ }^{29}$ and three expressed the sperm morphology by $\%$ of abnormal forms, ${ }^{30,33,34}$ including only two with the same classification according to WHO guidelines. ${ }^{33,34}$ Although these two studies showed a tendency or a significant increase in abnormal forms in exposed men $\left(\mathrm{CS}_{2}\right.$ for Ma et $\mathrm{al}^{34}$ and DMF for Chang et $\left.\mathrm{al}^{33}\right)$, the meta-analysis probably lacked power to detect a significant variation in sperm morphology between exposed and unexposed men.

The absence of a significant impact on sperm motility and vitality from occupational exposure to the solvents analyzed in the seven selected studies of our meta-analysis could be related to the various expected mechanisms of action of $\mathrm{GE},{ }^{31,32}$ aromatic solvents, ${ }^{27,29,30}$ and DMF. ${ }^{33}$ Indeed, for GE exposures, in accordance with studies from Welch et $\mathrm{al}^{31}$ and Ratcliffe et al, ${ }^{32}$ Multigner et $\mathrm{al}^{21}$ showed no difference in sperm progressive motility or viability between the exposed and control groups. The main mechanism of reprotoxic action of GE is toxicity to the germinal epithelium of the testis in animals ${ }^{48}$; this mechanism is expected to particularly impact sperm concentration but not sperm motility and vitality. Conversely, for aromatic solvents and DMF, the impact on motility is expected to be related to their mechanism of reprotoxic action. Indeed, among aromatic solvents, benzene metabolites and free radicals can generate lipid peroxidation that modifies the sperm plasma membrane and may decrease sperm motility ${ }^{49}$ and toluene could induce physicochemical alterations of the seminal plasma, which can also modify sperm motility. ${ }^{50}$ DMF could impair mitochondrial function that is a very important factor of sperm motility. ${ }^{51}$

One limit of our study is the heterogeneity we observed in our meta-analysis; it may be related to the various types of solvents to which workers were occupationally exposed in the studies we selected: 2-ME and 2-EE, ${ }^{31,32} \mathrm{PCE},{ }^{30}$ hydrocarbons, ${ }^{27,29} \mathrm{DMF},{ }^{33}$ and $\mathrm{CS}_{2}{ }^{34}$ Indeed, the impact on semen parameters can vary depending on the solvent's nature.

Another potential confounding factor could be the methodology used for semen analysis. In all the selected studies, semen analysis was performed according to the WHO criteria. Between 1988 (the oldest study included in the meta-analysis) and 2010 (the newest), the normality thresholds were revised in 1992, 1999, and $2010 .^{52}$ Consequently, the various studies do not use the same definitions of semen parameter normality; nevertheless, this did not influence our results. Indeed, the meta-analysis was based on numerical and not qualitative data (oligospermia, asthenospermia, or teratospermia). 


\section{CONCLUSION}

This meta-analysis showed a statistical negative impact on ejaculate volume and sperm concentration in male workers following occupational exposure to solvents. These results highlight the importance of information regarding reprotoxic risks in the workplace, in order to efficiently prevent these kinds of exposures in men of reproductive age. In the medical care of infertile patients, the search for environmental factors, including occupational exposure to solvents, could be useful to increase the success rate by improving prevention in the workplace.

\section{REFERENCES}

1. Bonde JP. Male reproductive organs are at risk from environmental hazards. Asian J Androl. 2010;12:152-156.

2. Hooiveld M, Haveman W, Roskes K, et al. Adverse reproductive outcomes among male painters with occupational exposure to organic solvents. Occup Environ Med. 2006;63:538-544.

3. Health Council of the Netherlands. Occupational Exposure to Organic Solvents: Effects on Human Reproduction. The Hague: Health Council of the Netherlands; 2008: publication no 2008/11OSH.

4. Multigner L, Droz P-O, Dutertre H, et al. Ethers de Glycol. Synthèse des connaissances sur les expositions de la population française générale et professionnelle. AFSSET,. 2008.

5. Swan SH, Beaumont JJ, Hammond SK, et al. Historical cohort study of spontaneous abortion among fabrication workers in the Semiconductor Health Study: agent-level analysis. Am J Ind Med. 1995;28: 751-769.

6. Ahlborg G, Hemminki K. Reproductive effects of chemical exposures in health professions. J Occup Environ Med. 1995;37:957-961.

7. Jelnes JE. Semen quality in workers producing reinforced plastic. Reprod Toxicol. 1988;2:209-212.

8. Kolstad HA, Bonde JP, Spano M, et al. Change in semen quality and sperm chromatin structure following occupational styrene exposure. ASCLEPIOS. Int Arch Occup Environ Health. 1999;72:135-141.

9. Lemasters GK, Olsen DM, Yiin JH, et al. Male reproductive effects of solvent and fuel exposure during aircraft maintenance. Reprod Toxicol Elmsford $N$. 1999; 13:155-166.

10. Katukam V, Kulakarni M, Syed R, et al. Effect of benzene exposure on fertility of male workers employed in bulk drug industries. Genet Test Mol Biomark. 2012;16:592-597.

11. Veulemans H, Steeno O, Masschelein R, et al. Exposure to ethylene glycol ethers and spermatogenic disorders in man: a case-control study. $B r J$ Ind Med. 1993;50:71-78.

12. Cherry N, Labrèche F, Collins J, et al. Occupational exposure to solvents and male infertility. Occup Environ Med. 2001;58:635-640.

13. Cook RR, Bodner KM, Kolesar RC, et al. A cross-sectional study of ethylene glycol monomethyl ether process employees. Arch Environ Health. 1982;37:346-351.

14. Rasmussen K, Sabroe S, Wohlert M, et al. A genotoxic study of metal workers exposed to trichloroethylene. Sperm parameters and chromosome aberrations in lymphocytes. Int Arch Occup Environ Health. 1988;60: 419-423.

15. Vanhoorne M, Comhaire F, De Bacquer D. Epidemiological study of the effects of carbon disulfide on male sexuality and reproduction. Arch Environ Health. 1994;49:273-278.

16. Mantel N, Haenszel W. Statistical aspects of the analysis of data from retrospective studies of disease. J Natl Cancer Inst. 1959;22: 719-748.

17. DerSimonian R, Laird N. Meta-analysis in clinical trials. Control Clin Trials. 1986; 7:177-188.

18. Higgins JPT, Thompson SG, Deeks JJ, et al. Measuring inconsistency in meta-analyses. BMJ. 2003;327:557-560.

19. Vassos E, Collier DA, Fazel S. Systematic meta-analyses and field synopsis of genetic association studies of violence and aggression. Mol Psychiatry. 2014; 19:471-477.

20. Borenstein M, Hedges LV, Higgins JPT, et al. A basic introduction to fixedeffect and random-effects models for meta-analysis. Res Synth Methods. 2010;1:97-111.

21. Multigner L, Ben Brik E, Arnaud I, et al. Glycol ethers and semen quality: a cross-sectional study among male workers in the Paris Municipality. Occup Environ Med. 2007;64:467-473.
22. Migliore L, Naccarati A, Zanello A, et al. Assessment of sperm DNA integrity in workers exposed to styrene. Hum Reprod Oxf Engl. 2002;17: 2912-2918.

23. Oliva A, Spira A, Multigner L. Contribution of environmental factors to the risk of male infertility. Hum Reprod Oxf Engl. 2001;16:1768-1776.

24. De Fleurian G, Perrin J, Ecochard R, et al. Occupational exposures obtained by questionnaire in clinical practice and their association with semen quality. J Androl. 2009;30:566-579.

25. Kurinczuk JJ, Clarke M. Case-control study of leatherwork and male infertility. Occup Environ Med. 2001;58:217-224.

26. Tielemans E, Burdorf A, te Velde ER, et al. Occupationally related exposures and reduced semen quality: a case-control study. Fertil Steril. 1999;71: 690-696.

27. Xiao G, Pan C, Cai Y, et al. Effect of benzene, toluene, xylene on the semen quality and the function of accessory gonad of exposed workers. Ind Health. 2001;39:206-210.

28. Xiao G, Pan C, Cai Y, et al. Effect of benzene, toluene, xylene on the semen quality of exposed workers. Chin Med J (Engl). 1999;112:709-712.

29. De Celis R, Feria-Velasco A, González-Unzaga M, et al. Semen quality of workers occupationally exposed to hydrocarbons. Fertil Steril. 2000;73: $221-228$.

30. Eskenazi B, Wyrobek AJ, Fenster L, et al. A study of the effect of perchloroethylene exposure on semen quality in dry cleaning workers. Am J Ind Med. 1991;20:575-591.

31. Welch LS, Schrader SM, Turner TW, et al. Effects of exposure to ethylene glycol ethers on shipyard painters: II. Male reproduction. Am J Ind Med. 1988;14:509-526.

32. Ratcliffe JM, Schrader SM, Clapp DE, et al. Semen quality in workers exposed to 2-ethoxyethanol. Br J Ind Med. 1989;46:399-406.

33. Chang H-Y, Shih T-S, Guo YL, et al. Sperm function in workers exposed to N,N-dimethylformamide in the synthetic leather industry. Fertil Steril. 2004;81:1589-1594.

34. Ma J-Y, Ji J-J, Qing Ding. et al. The effects of carbon disulfide on male sexual function and semen quality. Toxicol Ind Health. 2010;26:375-382.

35. Wyrobek AJ, Gordon L, Watchmaker G, et al. Human sperm morphology testing: description of reliable method and its statistical power. Genotoxic Expo;. 1982;527-541.

36. Cooper TG, Noonan E, von Eckardstein S, et al. World Health Organization reference values for human semen characteristics. Hum Reprod Update. 2010;16:231-245.

37. Sasagawa I, Nakada T, Kazama T, et al. Testosterone replacement therapy and prostate/seminal vesicle volume in Klinefelter's syndrome. Arch Androl. 1989;22:245-249.

38. Regulation (CE) no $1272 / 2008$ of the European Parliament and of the Council of 16 December 2008, on Classification, Labelling and Packaging of Substances and Mixtures.

39. Wägar G, Tolonen M, Stenman UH, et al. Endocrinologic studies in men exposed occupationally to carbon disulfide. J Toxicol Environ Health. 1981;7:363-371.

40. Zhang X, Qian Y, Sun X-L, et al. Effects of N,N-dimethylformamide reproductive endocrine of male workers. Zhongguo Zhiye Yixue. 2005;32: $10-12$.

41. Billig H, Furuta I, Rivier C, et al. Apoptosis in testis germ cells: developmental changes in gonadotropin dependence and localization to selective tubule stages. Endocrinology. 1995;136:5-12.

42. Ono A, Kawashima K, Sekita K, et al. Toluene inhalation induced epididymal sperm dysfunction in rats. Toxicology. 1999;139:193-205.

43. Svensson BG, Nise G, Erfurth EM, et al. Neuroendocrine effects in printing workers exposed to toluene. Br J Ind Med. 1992;49:402-408.

44. Xing C, Marchetti F, Li G, et al. Benzene exposure near the U.S. permissible limit is associated with sperm aneuploidy. Environ Health Perspect. 2010;118:833-839.

45. Song B, Cai Z, Li X, et al. Detection of sperm DNA damage in workers exposed to benzene by modified single cell gel electrophoresis. J Reprod Contrac. 2005; 16:131-136.

46. Marchetti F, Eskenazi B, Weldon RH, et al. Occupational exposure to benzene and chromosomal structural aberrations in the sperm of Chinese men. Environ Health Perspect. 2012;120:229-234.

47. Smith MT. Mechanistic studies of benzene toxicity: implications for risk assessment. Adv Exp Med Biol. 1996;387:259-266.

48. Foster PM, Creasy DM, Foster JR, et al. Testicular toxicity produced by ethylene glycol monomethyl and monoethyl ethers in the rat. Environ Health Perspect. 1984;57:207-217. 
49. Shen Y, Shen HM, Shi CY, et al. Benzene metabolites enhance reactive oxygen species generation in HL60 human leukemia cells. Hum Exp Toxicol. 1996;15:422-427.

50. Mendeluk GR, Munuce MJ, Carizza C, et al. Sperm motility and ATP content in seminal hyperviscosity. Arch Androl. 1997;39: $223-227$.
51. Macleod J, Gold RZ. The male factor in fertility and infertility. III. An analysis of motile activity in the spermatozoa of 1000 fertile men and 1000 men in infertile marriage. Fertil Steril. 1951;2:187-204.

52. Esteves SC. Clinical relevance of routine semen analysis and controversies surrounding the 2010 World Health Organization criteria for semen examination. J Urol. 2014;40:443-453. 